\title{
Subsistence, Environment and Mesolithic Landscape Archaeology
}

\author{
Barry Taylor
}

\begin{abstract}
Since the 1970s, research into Mesolithic landscapes has been heavily influenced by economic models of human activity where patterns of settlement and mobility result from the relationship between subsistence practices and the environment. However, in reconstructing these patterns we have tended to generalize both the modes of subsistence and the temporal and spatial variability of the environment, and ignored the role that cultural practices played in the way subsistence tasks were organized. While more recent research has emphasized the importance that cultural practices played in the way landscapes were perceived and understood, these have tended to underplay the role of subsistence and have continued to consider the environment in a very generalized manner. This paper argues that we can only develop detailed accounts of Mesolithic landscapes by looking at the specific forms of subsistence practice and the complex relationships they created with the environment. It will also show that the inhabitation of Mesolithic landscapes was structured around cultural attitudes to particular places and to the environment, and that this can be seen archaeologically through practices of deposition and recursive patterns of occupation at certain sites.
\end{abstract}

\section{Introduction}

Historically, we have studied Mesolithic landscapes through the economic interactions between people and their environment. Drawing parallels with anthropological studies of hunter-gatherers, patterns of Mesolithic activity are assumed to have related to the availability of environmental resources. As the nature of the environment would have differed both spatially and seasonally, the character of activity is assumed to have varied across the landscape as groups exploited different types of resources, in different places and at different times of the year.

In seeking to identify such patterns archaeologically, we have generally taken one of two approaches. The first has been to model activity within the landscape by predicting the way people would have responded to the resources provided by the environment. In some cases these models are relatively informal and based largely upon inferences of human behaviour drawn from ethnographic examples (e.g. Clark 1972; Simmons 1975). In others, more formal mathematical models have been constructed in which the relationships between patterns of activity and resources are established through calculations of factors such as yield, risk and efficiency (e.g. Jochim 1976; Mithen 1990; Price 1978). The second has been to infer a relationship between patterns of settlement and mobility and the environment on the basis of spatial variability seen in archaeological assemblages across particular landscapes. Here, sites are placed into categories of economically interrelated types drawn from the ethnographic record, such as hunting camp or base camp, on the basis of functional interpretations of the archaeological material. Spatial patterning in the distribution of site types is then explained in terms of the organization of tasks in relation to inferred environmental resources and cycles of seasonal mobility (e.g. Jacobi 1978; Mellars 1976). These two methods are not mutually exclusive and predictive 
models of behaviour (whether formal or informal) are frequently used to interpret spatial patterning in the archaeological record (e.g. Donahue \& Lovis 2006), while mathematical models often draw upon functional interpretations of site types (e.g. Price 1978).

The widespread application of such approaches has had a profound influence on Mesolithic archaeology. Categories of site type, particularly 'base camps' and 'hunting camps', have become an established part of our lexicon, as has the concept of a seasonally mobile society. However, since the 1990s, there has been growing criticism both of the way in which patterns of settlement and mobility have been reconstructed and the resulting view this creates of Mesolithic landscapes and life more generally. To begin with, Jochim (1991) has argued that the models of seasonal mobility employed by archaeologists failed to appreciate the more flexible, variable patterns seen in the ethnographic record. While archaeological models emphasized broad, cyclical seasonal rounds, ethnographic accounts describe considerable diversity in scales of mobility and site location, either within a particular season, or from year to year (Jochim 1991). Similarly, the categorization of sites into a narrow range of functional types has been criticized for generalizing the more complex patterns of site organization recorded in the ethnographic literature and failing to recognize both the degree of variability seen in archaeological assemblages and the fact that many are generated through repeated, but different, episodes of activity (Conneller 2005; Spikins 1999). Finally, Spikins (1999) has argued that the effect that the environment had upon the spatial patterning of activity is, at best, an estimate, given our poor understanding of Mesolithic ecologies and the relative yields of different plant and animal resources.

In response to these criticisms, more sophisticated models of Mesolithic landscapes have been developed that deal more directly with nuances of the archaeological data and the economic relationships between activity and environment (e.g. Jochim 1998; Myres 2015; Spikins 1999). At the same time, there has been a move towards more social accounts of Mesolithic landscapes, which have addressed a growing dissatisfaction with the earlier, more economically focused approaches. While methodologies have varied, a key theme is that landscapes were created and reproduced through the habitual, routine practices of people's lives. Here, the spatial and seasonal patterns in subsistence and settlement, the movement of materials and the making of things are seen as creating connections between people, places and times in the landscape (e.g. Amkreutz 2013; Conneller 2005;
Edmonds 1997; McFadyen 2006). Related to this has been a change in the way we have viewed people's relationship with the environment. Rather than seeing human action as being determined by environmental resources, ethnographic studies have shown how interactions with plants, animals and the landscape more generally are structured by cultural rules (e.g. Jordan 2003a; Nelson 1983). These can include particular ways of moving through the landscape, the appropriateness of particular places or times for certain forms of activity, and acts of deposition that accompany economic practices such as the killing of animals. Drawing on these ethnographic observations, a number of studies have discussed how people's engagement with plants and animals in the Mesolithic may have been structured by similar rules, noting in particular the presence of prescribed forms of deposition relating to the disposal of animal remains and artefacts made from them (e.g. Conneller 2004; Overton \& Taylor in press; Taylor et al. 2017).

While these approaches have resulted in richer narratives of Mesolithic life, several issues remain outstanding. First, these recent accounts have been criticized for relying upon broad, cross-cultural observations when discussing how Mesolithic people perceived and understood their landscape (e.g. Jordan 2003b). Jordan has argued that a more fruitful approach would be to consider the way that people 'enculturate' their landscape through interrelated ritual and economic practices, as seen in the ethnographic record from hunting societies in Northern Eurasia (Jordan 2003a,b). According to Jordan, these result in distinctive material assemblages, often associated with particular places, that could be used to identify comparable forms of activity in the Mesolithic. Second, few studies have provided a detailed account of people's relationship with their environment that deals with both the richness and diversity of the local ecology and the specific practices through which people engaged with it. This can only be achieved through a more detailed application of local palaeoenvironmental data and a move away from broad descriptions of economic activity, such as 'hunting', 'gathering' and 'foraging'.

This paper will address these issues through a case study set in the early Mesolithic landscape of Lake Flixton in the eastern Vale of Pickering (North Yorkshire, UK). Drawing on recent palaeoenvironmental and archaeological work in the area, the paper will discuss the ways in which people engaged with their environment and how economic practices, as well as cultural traditions, structured the ways in which they inhabited this landscape. 


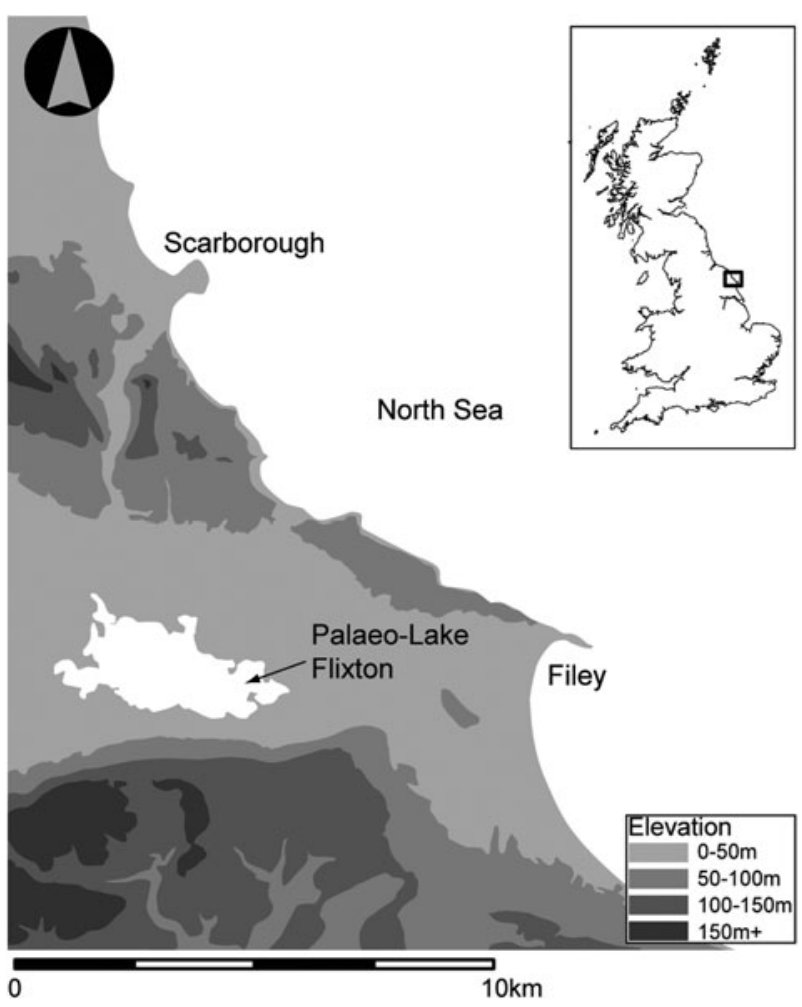

Figure 1. Location of Lake Flixton.

\section{The Mesolithic landscape of Lake Flixton and the eastern Vale of Pickering}

Lake Flixton lay at the eastern end of the Vale of Pickering, a narrow valley separating the uplands of the North York Moors (to the north) from the Yorkshire Wolds (to the south) (Fig. 1). The lake formed at the start of the Late Glacial Interstadial and gradually infilled with calcareous and organic sediments throughout the Late Glacial and early Post Glacial (Taylor 2012). These sediments have preserved faunal remains, wood and an array of organic material culture, as well as pollen and plant macrofossils that provide a record of the contemporary environment.

Fieldwork carried out in this area since the mid 1940s has recorded evidence for early Mesolithic activity from numerous locations around the lake (Fig. 2). The best known of these is Star Carr, where excavations in the mid twentieth century recorded large assemblages of faunal remains and material culture made from animal bone, antler and wood within the lake-edge deposits (Clark 1954). Using data from this and other sites in the area, generations of archaeologists have sought to identify patterns of early Mesolithic activity within this landscape, focusing in particular on the relationship between settlement and mobility and the environment.

Following the excavation of Star Carr, Clark interpreted the site as a seasonally occupied residential camp inhabited in the winter and spring (Clark $1954,10)$. This was revised in the early 1970s, when he placed the site within a model of seasonal uplandlowland migration where communities aggregated at Star Carr during winter and spring, but dispersed into smaller groups during the summer as they moved onto upland sites following migrating herds of red deer (Clark 1972). Clark's model was based largely upon ethnographic analogy and observations of modern red deer populations. In the following years, however, it received a firmer archaeological foundation through work carried out by Jacobi (1978), who identified functional differences in lithic assemblages between lowland sites in the Vale of Pickering, south Yorkshire and Lincolnshire and broadly contemporary upland sites in the southern Pennines and North York Moors. This, he argued, reflected differences in hunting, butchery and craft activities carried out in the wooded winter lowlands and the more open summer uplands.

In the following decades, reanalysis of the material from Clark's excavations and new investigations at other sites around the lake led to a more detailed consideration of patterns of activity within this landscape. Legge and Rowley-Conwy (1988) reinterpreted Star Carr as a hunting camp occupied in the summer by hunters who visited the area to predate upon juvenile red deer. Subsequent work by Rowley-Conwy (1995) led him tentatively to interpret Seamer Carr as a summer residential camp and Barry's Island (a peninsula at the western end of the lake) as a potential winter base. Both studies also assumed that the lake formed part of a seasonal migratory cycle, possibly involving winter base camps on the North Sea coast. Following further excavations at Star Carr, Mellars (1998) reinterpreted the site again, this time as a summer base camp used by groups exploiting local plant and animal resources, while possibly also undertaking short-term hunting trips to the North York Moors and journeys to the coast. More recently, Donahue and Lovis (2006) placed activity around Lake Flixton into a more extensive settlement pattern that extended from the Pennines to the North Sea coast. In this model, Star Carr acted as a residential winter base, while sites at Seamer Carr functioned as logistical camps from which groups embarked on short-distance forays onto the North York Moors, and longer-distance expeditions onto the Pennines. Seasonal migration took these groups to residential sites on the coast in the summer and autumn, though 


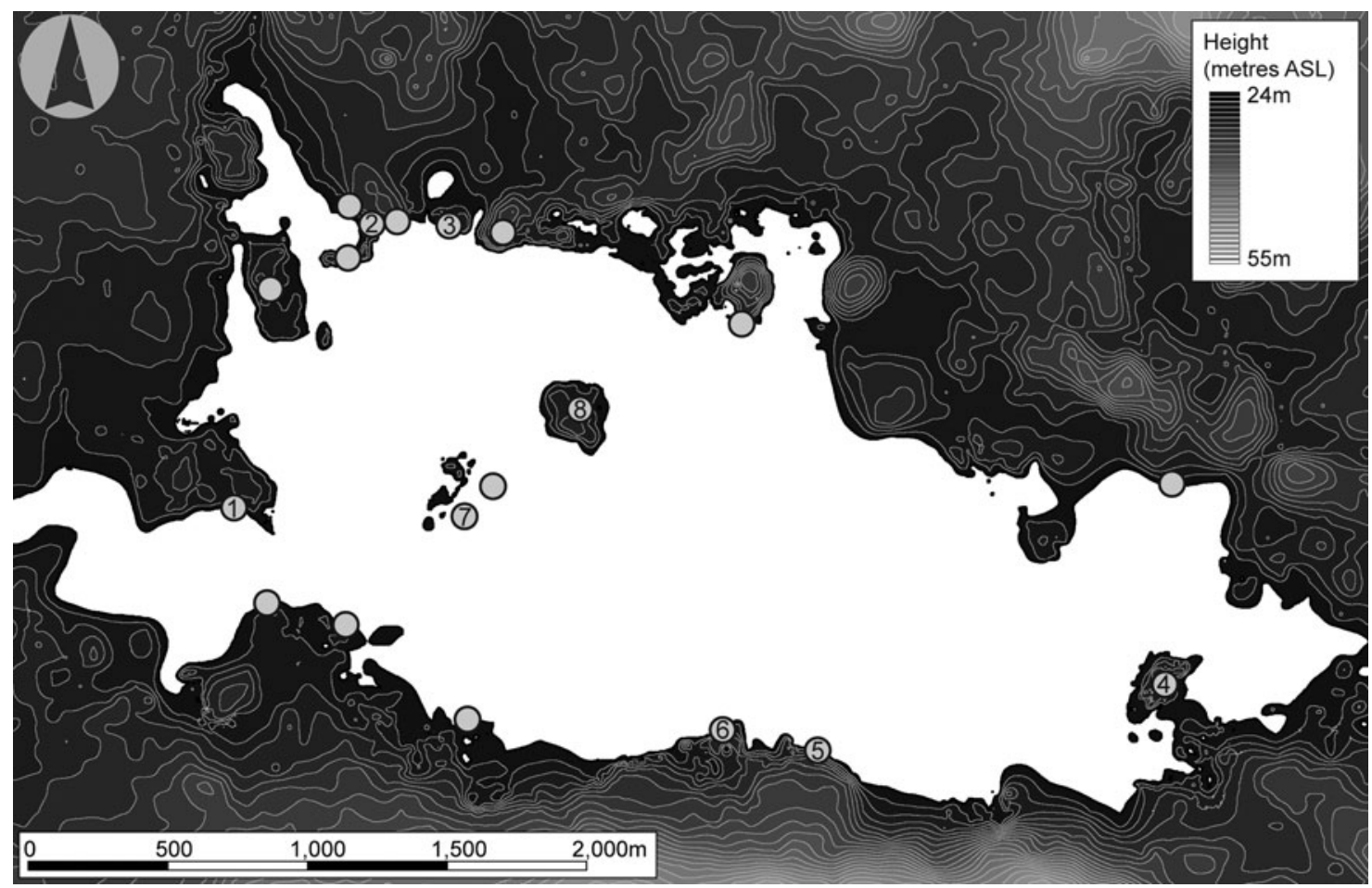

Figure 2. Areas of early Mesolithic activity recorded around Lake Flixton. Sites referred to in the text: (1) Star Carr; (2) Seamer Carr Site K; (3) Seamer Carr Site C; (4) Barry's Island; (5) Flixton School Field; (6) Flixton School House Farm; (7) Flixton Island site 1; (8) No Name Hill. (Contours represent the terrestrial topography at $1 \mathrm{~m}$ intervals.)

sites around Lake Flixton continued to be used for hunting.

A similar economically focused approach has been applied to other British Mesolithic landscapes. On a regional level, Mellars (1976) identified a seasonal pattern of upland-lowland mobility based on differences in the composition of lithic assemblages from sites across Britain and Wales. Following Clark (1972), he argued that the sheltered lowland areas were occupied in the winter by groups who dispersed to small upland hunting camps in the summer. Economic patterns of settlement were also identified in the southeast of England on the basis of variability in lithic assemblages from different geological contexts (Mellars \& Reinhardt 1978). This was interpreted as reflecting variations in economic practices taking place in the different environments that would have formed in these areas. On a more local scale, early Mesolithic activity in the Kennet Valley (Berkshire) has been discussed in terms of temporary home bases and hunting camps located to exploit plant and animal resources (e.g. Ellis et al. 2003; Healy et al. 1992). Further north, Bonsall (1981) suggested that the distribution of late Mesolithic sites at Eskmeals (Cumbria) reflects shifting areas of economic activity along the estuary of the River Esk, while late Mesolithic coastal middens in Western Scotland were interpreted as specialized processing sites within a wider pattern of economic activity (Bonsall 1996).

Since the turn of the millennium, new research has focused on the cultural as well as the economic aspects of people's interactions with the Lake Flixton landscape. Analysis and refitting of lithic assemblages from sites around the lake, undertaken by Conneller (2000; 2005; Conneller \& Schadla-Hall 2003), has shown that activity was far more complex and varied than earlier models had suggested. Rather than a series of functionally interrelated site types, locations around the lake were being revisited on multiple occasions, often for very different reasons. By drawing together the different scales and tempos of action at these locations, Conneller showed how the landscape was actively produced through tasks that made connections between people, places, materials and times. Conneller (2004; Conneller \& Schadla-Hall 2003) and Chatterton (2003) also noted that much larger assemblages of osseous artefacts and faunal remains were present at Star Carr than at other sites in the local area. This led Chatterton to argue that the site was the focus for ritual feasting and deposition following successful 
hunts, while Conneller argued that it acted as a place in the landscape appropriate for the deposition of animal remains.

These studies formed part of a growing body of work on the British Mesolithic that considered the ways in which landscapes and environments were perceived and understood by the people who inhabited them (e.g. Cobb 2007; Mcfadyen 2006). The remainder of this paper will show how we can develop this work further by considering in more detail the nature of people's interactions with their environment, and the underlying patterns of activity that structured the way they inhabited their landscape.

\section{The early Mesolithic landscape of the Lake Flixton basin}

By the time Mesolithic groups arrived in this landscape Lake Flixton would have been a large body of water, flanked by shallow embayments and hilly peninsulas, and with two small islands (Fig. 2). A species-rich wetland environment was present within the shallower lake margins, comprising beds of Phragmites reeds and stands of sedge, bur-reed, cattails and rush, with communities of aquatic plants (white and yellow water-lily and species of pondweed) growing in the deeper water. The composition of these environments differed around the lake in response to the habitat preferences of the different plants, while their extents varied as undulations in the topography of the basin created significant differences in water depth (Taylor 2011; 2012) (Fig. 3a). At the water's edge, stands of aspen and species of willow and birch were growing along with nettles, species of fern, and fen plants suited to wet soils (Taylor 2012, 438). Beyond this was an undulating landscape of small, low hills interspersed with areas of low-lying ground and water-filled hollows flanked to the north and south by the steeper slopes of the adjacent uplands. Open grassland and scrub was initially present across this area, before birch woodland, with a rich and diverse understory, became established (Dark 1998, 169-70).

These environments developed throughout the early Mesolithic. Within the lake, the depth of water gradually shallowed, allowing swamp and fen environments to colonize the shallow embayments and expand into the basin from c. 8500 cal. BC (Fig. 3b \& c). At around the same time, hazel began to grow locally (Taylor 2012, 243). Initially, the tree probably formed small, discrete stands, but in the following centuries it expanded rapidly, replacing birch and shading out much of the understory vegetation (Dark 1998, 170). By the end of the early Mesolithic (c. 7500 cal. $\mathrm{BC})$, fen and carr filled the shallow embayments
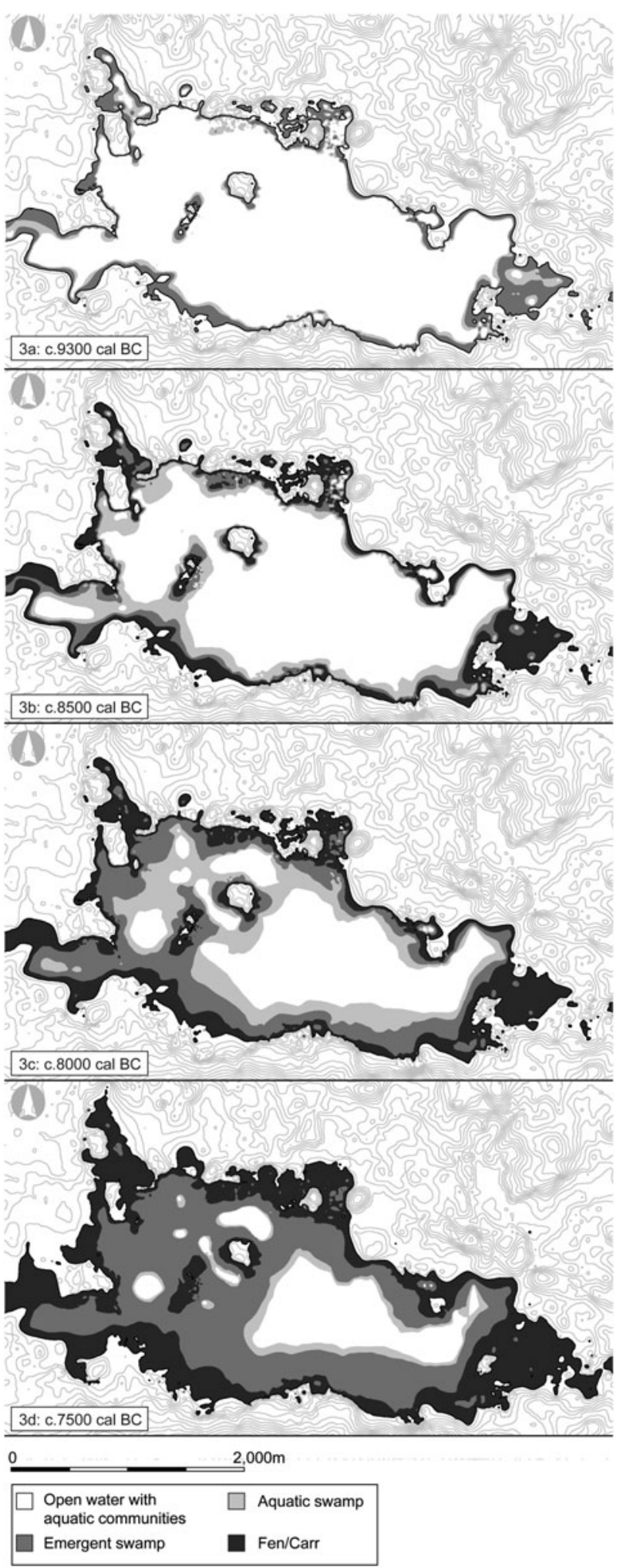

Figure 3. Extents of the wetland environments within Lake Flixton during the early Mesolithic. (Contours represent the terrestrial topography at $1 \mathrm{~m}$ intervals). 
and formed a dense fringe of vegetation around the lake, with swamp and aquatic communities expanding further into the basin. Above the shore, peatforming wetlands had started to encroach over lowlying ground, while elm and oak had begun to grow with hazel within the terrestrial woodlands (Dark 1998, 170) (Fig. 3d).

\section{Sites in the landscape}

The largest and most extensively excavated site around the lake is Star Carr, which occupied a large peninsula at the western side of the basin (Fig. 2). The site is best known for the excavations carried out by Grahame Clark, which recorded a large assemblage of osseous material culture (including barbed antler projectile points, bone bodkins and scraping tools, antler mattocks and axes and red deer antler frontlets or masks) as well as animal bone, antler, and flint that had been deposited in the reedswamp at the edge of the lake (Clark 1954). Recent excavations at the site have recorded several post-built structures on the shore, associated with dense concentrations of worked flint and animal bone, and a series of large timber platforms or trackways within the adjacent reedswamp (Conneller et al. 2012; Milner et al. in press), along with smaller quantities of animal bone, antler, worked flint and osseous artefacts (Milner et al. in press).

The site was occupied between c. 9300 cal. BC and 8500 cal. BC (Conneller et al. 2016, fig. 4), though the scale and focus of activity may have changed over time (Dark et al. 2006, 198). Seasonality indicators in the faunal assemblage recorded by Clark show that, of those animals where age-at-death could be determined, the majority were being killed in late winter or early spring (mostly February to March, but with a smaller proportion in April/May), with more occasional kills in the summer and autumn/early winter (Carter 1997; 1998; Legge \& Rowley-Conwy 1988). This suggests periods of more intensive occupation focused on the early part of the year (though not necessarily a single, consistent phase of activity), followed by more discrete episodes of activity on other occasions.

Other sites are much smaller, and with the exception of Seamer Carr sites $C$ and $K$ have been the subject of more limited investigation (Taylor 2012, 71). Evidence at these sites consists of scatters of worked flint deposited on the drier ground at, or just above, the lake shore, sometimes accompanied by poorly preserved animal remains (Lane \& Schadla-Hall forthcoming). Pits and hearths have been recorded at Seamer Carr and No Name Hill (Lane \& SchadlaHall forthcoming) and arrangements of stake- and post-holes were recorded in association with a series of pits and hollows at Flixton School House Farm (henceforth SHF) (Taylor \& Gray Jones 2009; Gray Jones \& Taylor 2015). In contrast to Star Carr, much smaller quantities of material (generally animal bone, antler and utilized flint flakes and blades) have been recorded from the wetlands adjacent to these sites.

Many of these sites also show evidence for repeated episodes of occupation (Conneller 2000; 2005; Conneller \& Schadla-Hall 2003), and although the chronologies are relatively poor some phases of activity are broadly contemporary with Star Carr. At No Name Hill, Flixton Island and Flixton SHF small assemblages of material were recorded at the base of the lake-edge peat sequence, placing them in deposits that had formed by c. $9000 \mathrm{cal}$. BC or earlier, while stratigraphically later material indicates occupation in the following centuries (Taylor 2011; 2012). In addition, Cummins has argued that phases of localized burning recorded at Flixton School Field are contemporary with burning events recorded by Dark (1998) at Star Carr (Cummins 2003, 293). The scale and intensity of activity at these locations also varied throughout the period. Cummins (2003, 233-4) identified at least two periods of localized burning at Flixton School Field, each lasting over a century and made up of intense episodes that spanned decades. A similar pattern was recorded on the north shore of No Name Hill, with at least three episode of burning in the early Mesolithic, two of which lasted several decades (Cummins 2003, 185). Taking the burning as a proxy for human activity, this suggests changes in the scale, intensity and / or character of activity at these locations over time.

\section{Economic practices around Lake Flixton}

Much of our evidence for economic practices come from Star Carr, where the large-scale excavations in the wetland deposits have provided information on the exploitation and use of different plant and animal species (Milner et al. in press). However, while the evidence is less comprehensive, comparable activities have also been documented at other sites, suggesting common forms of economic activity that were being undertaken at multiple sites within the landscape.

In terms of plant use, most of the evidence relates to the exploitation of shrubs and trees for use as raw materials. At Star Carr this consists of the utilization of aspen, species of willow and, more occasionally, birch for construction and the making of artefacts (Conneller et al. 2012; Milner et al. in press; Taylor 1998), and birch bark, either as a material or for the extraction of tar (Clark 1954; Milner et al. in press). 
The collection and utilization of shrubs and trees can also be inferred at No Name Hill, Flixton Island and Barry's Island, based on the presence of axes and axesharpening flakes (Conneller 2000), and from clusters of stake- and post-holes at Flixton SHF (Taylor \& Gray Jones 2009), while scatters of burnt flint at the majority of sites suggest the presence of hearths, which would involve the collection of wood for fuel (e.g. Conneller 2000). Coppiced wood (either willow or aspen) has been recorded at Star Carr (Milner et al. in press), Flixton SHF (Taylor 2012, 216), and No Name Hill (Cummins 2003, 108), though it is unclear whether these came from deliberately managed trees or resulted from the exploitation of natural coppice.

Tasks involving the collection of wetland plants can also been inferred from scatters of utilized flint flakes and blades that have been recorded from the lake-edge deposits at Star Carr (Mellars \& Conneller 1998), No Name Hill (Conneller 2000, 210), Flixton Island (Taylor 2012, 457) and Flixton SHF (Taylor 2012, 230). On the basis of use-wear studies carried out at other north European Mesolithic sites, these were probably used for collecting siliceous plants, such as bulrush, cattail or bur-reed, for use in the manufacture of cord, nets, or baskets (e.g. Van Gijn et al. 2001, 191). The wetland vegetation was also deliberately burnt at Star Carr (Dark 1998) and Flixton School Field (Cummins 2003), either to clear the lake-edge swamp or to remove invasive species and create monolithic stands of reed. Evidence for the collection of plant foods derives entirely from Flixton SHF, where carbonized remains of hazelnut, wild cherry and crab apple have been recorded (Gray Jones \& Taylor 2015). However, yellow water-lily and species of cattail are known to have been used for food during the Mesolithic (e.g. Out 2009, 359; Perry 1999, 234), and are likely to have been utilized by groups inhabiting this area.

A diverse range of animals was also hunted in this landscape. Large and medium mammals, notably red deer, but also elk, aurochs, roe deer and wild boar are all well represented in the faunal assemblage from Star Carr (Clark 1954; Legge \& RowleyConwy 1988; Milner et al. in press) and have been found in smaller quantities at Seamer Carr Sites $C$ and K, Barry's Island, Flixton School Field, Flixton SHF and No Name Hill (Cummins 2003; Rowley-Conwy 1995; Taylor 2012; Uchiyama 2016). This material, as well as the large quantities of barbed antler projectile points at Star Carr, indicate the importance of large game hunting in this landscape. However, small game hunting or trapping, as well as fowling and fishing, also played at least a part in the economic practices in the area. The remains of smaller mammals (including beaver, pine marten, badger, hare and fox) and species of wild fowl have been recorded at Star Carr (Clark 1954), while the bones of pike, perch and a species of carp have recently been discovered in Mesolithic contexts at both Star Carr and Flixton Island (Robson et al. 2016). While these generally occur in very small quantities (with the exception of beaver), their poor representation is more likely to be a product of differential preservation and recovery than a reflection of their economic importance (cf. Robson et al. 2016). This also applies to microfauna, which may also have contributed to people's diets, but have failed to survive archaeologically.

\section{The diversity of hunting and gathering}

The practices involved in the collection of these different plants or the hunting of these animals were diverse, involving specific forms of technology, skill and knowledge that varied depending upon the properties or behaviours of the particular species and the motivations of those undertaking the task. At Star Carr, for example, the split timbers used in the wooden platforms came from willow and aspen trees selected for their straight growth and lack of side branches (Bamforth et al. in press). In contrast, thinner stems (mostly willow), which were used to manufacture handles, hafts or artefacts such as digging sticks, were harvested from natural or deliberately managed coppiced stands using axes (Milner et al. in press). Other plant species were collected in different ways: wetland plants, probably species of reed, were harvested from the lake edge using large flint flakes and blades; the collection of hazelnuts and fruits would have been carried out by hand, but probably also involved the use of baskets or bags made from hide or plant fibres; roots or tubers were probably extracted using digging sticks or antler mattocks of the sort recorded at Star Carr (Clark 1954, 14); and if people were utilizing water-lilies for food, then canoes or other watercraft would have been employed in order to access areas of deep water.

A similarly diverse range of practices was involved in the hunting and killing of animals. At a general level the larger mammals were hunted by groups of people using projectiles. Impact injuries caused by osseous or lithic weapon tips have been recorded on scapulae of two elk and a red deer from Star Carr (Legge \& Rowley Conwy 1988; Noe-Nygaard 1975), and comparable injuries have been noted on bones from large mammals at Mesolithic sites in Denmark (Leduc 2014; Noe-Nygaard 1974). Given the nature of the injuries and their locations on the skeleton, these are thought to have been inflicted by arrows, darts, or throwing spears fired from multiple directions (Leduc 2014, 488; Noe-Nygaard 1974, 242-3). 
Hunting strategies for these larger animals involved targeting solitary animals, or separating individuals from herds (Legge \& Rowley-Conwy 1988, 42-3; Overton \& Taylor in press); however, the specific tactics and technologies that were utilized and the attendant knowledge that people drew upon would have varied considerably between species. Traditional methods of stalking elk, for example, differ from those of other large mammals due to the tendency of the animal to double back on itself (e.g. Nelson 1986, 106), while the tactics used to hunt and kill young red deer are likely to have differed from those employed for older, more experienced animals. Similarly, methods employed when hunting aggressive animals would be different to those used on species more prone to flight. This appears to have been the case with wild boar, where the presence of impact injuries caused by weapons such as axes on the skulls of the animals from sites in Denmark (Noe-Nygaard 1974, 238) suggests that they may have been encountered at closer quarters than other species.

Other forms of technical practice would have been used to capture and kill the smaller mammals. Beavers are likely to have been killed at their lodges by hunters using spears or bows, or caught in submerged traps (Boas 1905, 510); pine marten would have been caught in deadfalls set in cubbys (branches used to disguise the trap) (Nelson 1986, 240), and hares would be caught in spring-pole snares, or a simple snare set across a trail (Nelson 1986, 136-9). Different practices would have been used to hunt birds, either using nets or projectiles, while nets, harpoons, or bows and arrows would have been used for fishing (Robson et al. 2016).

Cutting across this diversity in practice were differences in the scales at which tasks were undertaken and the social contexts in which they were carried out. Depending upon the circumstances and motivations behind a particular activity, the scales at which they were carried out would vary significantly, from the expedient selection of a single willow stem to replace a broken haft to the intensive collection of reeds or food plants. Similarly, the number of people involved in tasks, and the social composition of these groups, could differ. Some tasks were intrinsically cooperative, involving the collaborative efforts of groups of people. This would be particularly true of large mammal hunting, but would also be the case in tasks such as the felling of large trees for timber, the harvesting of reeds at the water's edge, or the collection of food plants. In contrast, tasks such as checking traps and snares may have been undertaken alone, or in the company of smaller groups of people.
While we cannot directly observe the social composition of these groups, we should not assume that the binary gender division of labour often presented in the archaeological literature, where hunting is carried out by men and older boys (e.g. Donahue \& Lovis 2006, 253) and the collection of plant foods is undertaken by women and younger children, is correct. The ethnographic record shows that the relationship between subsistence tasks and gender is complex and far from universal. In some cases, large mammal hunting is an all-male activity, though women still trap and fish (e.g. Willoughby 1963); in others, women participate in all aspects of hunting, though not always the act of killing the animal (e.g. Jarvenpa \& Brumbach 2006). The same is true of the collection of plants, which can be associated with particular genders or undertaken by everyone (e.g. Jolles 2006; Willoughby 1963). In addition, the hunting of certain animals or the collection of particular plants can be restricted to a specific gender, or to particular individuals (e.g. McGuire \& Hildebrandt 1994).

Furthermore, participation in some tasks may have varied with age. Elderly adults, for example, do not always participate in large mammal hunting, but maintain active roles in trapping and snaring, tasks that are also carried out by mothers with younger children (e.g. Nelson 1983, 134). Similarly, the role of children in subsistence practices gradually develops as they learnt the requisite skills (e.g. Jolles 2006). Finally, while participation in certain tasks may have been defined by gender or age, the tasks themselves may have formed parts of collaborative projects involving the cooperation of other people. Building the structures at Star Carr or Flixton SHF, for example, involved a range of tasks, such as collecting the thin stems used for the frame, bark or reed for the walls and roof, and plant materials for the floor, each of which may have been undertaken by different groups of individuals (e.g. Willoughby 1963, 44).

Though the evidence for subsistence around Lake Flixton is unlikely to be complete, it is clear that there is significant diversity in economic practices and that this has implications for the way we understand the inhabitation of this landscape. Rather than viewing such practices in terms of broad categories of activity (e.g. hunting) and the exploitation of generic environments (e.g. wetlands), people were undertaking very specific tasks, focusing on particular plant or animal species and utilizing specific forms of technology, skill and knowledge. As such, interactions with the environment were complex, varying in character, scale and the social context in which they took place. Furthermore, when we consider this diversity in 
relation to the contemporary environment, we can begin to see how patterns of activity were structured across the landscape.

\section{Patterns of settlement and mobility}

Broadly speaking, the organization of different economic tasks would have related to the distribution of environmental resources. However, the diversity of plant and animal species and the spatially and temporally varied character of the environment meant that particular tasks would have been undertaken in different, and often very specific, places around the lake.

At a very general level, the collection of plants would have been tied to particular environments depending upon the ecological preferences of the target species. In some cases species were common enough that they could be collected at a wide range of locations, as was the case for the collection of wetland plants, which has been documented at several sites around the lake. In others, variations in abundance would have meant that plants were not only limited to particular ecological habitats, but to specific places within them. Plant macrofossil analysis has suggested that the distribution of wetland species may have been uneven around the lake (Taylor 2012, 427). The same would have been true of hazel during the early appearance of the tree in the landscape, and also species such as cherry and apple, which are poorly represented in the local pollen records. Furthermore, even amongst the more common species, plants with the specific characteristics that people required, such as straight growth in the willow and aspen trees used for producing split timbers, would have been unevenly distributed.

Different forms of hunting, trapping and fishing would also have focused on particular areas where specific species could be killed, trapped, or caught. Deer and elk, for example, are likely to have visited thickets of willow and aspen, or more open areas within the woodland to browse on young plants. These animals would also have favoured open areas around the edges of thickets with clear lines of sight and unimpeded escape routes, and avoided locations that limited mobility and visibility (e.g. Ripple \& Beschta 2004). Aurochs may have come to areas around the edge of the wetlands to feed on reeds and sedges (Hall 2008) and elk, which graze on wetland plants (particularly pondweed), would have visited areas of the lake where these were most abundant. Similarly, the behaviours and habitat preferences of smaller mammals, birds and fish would have made them easier to shoot, trap, or catch at particu- lar locations. Communities of waterfowl, for example, may have inhabited the swamp-filled embayments at Seamer Carr or Lingholme, while the presence of beaver-gnawed wood at Flixton SHF (Taylor 2012, $175)$ shows that the animal was visiting wooded areas along the shore. Similarly, pike are attracted to the detritus of human occupation and so may have been shot or caught at the lake edge near to areas of settlement (Robson et al. 2016).

The areas where tasks were undertaken would also have varied temporally. To begin with, the growth patterns of different plants would have focused tasks associated with their collection to particular places at certain times of the year. This is true of plant foods, where gathering fruits and nuts would have been limited to the times of year these ripened (late spring-early summer for wild cherry, late summer for hazelnuts), but it would also have affected tasks such as the collection of reed or nettle for use as a material, as these tend to die in the winter and cannot be worked. Similarly, hunting practices would have varied throughout the year as the habitats and behaviours of animals changed. Seasonal variations in plant growth would have resulted in differences in the availability of food for animals, changing their movement within the landscape while also altering the cover for hunters approaching their prey or waiting in ambush. Furthermore, seasonal changes in animal behaviour relating to breeding patterns, such as the red and roe deer ruts, would have altered the distribution and abundance of animals of particular ages, affecting the locations where they could be hunted and killed. Finally, if people were revisiting the landscape at different times of the year, then the social composition of the groups undertaking these tasks could also have changed. In this way, not only would patterns of activity change throughout the year, but they may also have involved people of differing ages, genders, kin groups and so forth.

\section{Structured patterns of activity}

These interactions between forms of economic practice and the spatial and temporal variability of the environment resulted in a complex and diverse pattern of human activity within the landscape. Yet within this diversity was a structure to the way in which activity was organized. The distributions of plants and animals may have been spatially and temporally varied, but were also consistent and predictable at the scale of human lifetimes. As a result, tasks such as the collection of particular plants or the hunting of certain animals would have involved repeated visits to the same places at similar times, creating recursive 
patterns of movement and activity within the landscape. But while these patterns may have related to the distribution of environmental resources, they were not necessarily determined by them. Certain forms of human activity would have modified the environment in ways that would have affected the distribution of plants and animals. The harvesting of coppice from natural stands, for example, would have caused the plants to produce renewed growth of long, straight poles, creating a resource that people would return to on inter-annual cycles. Similarly, the management of the reedbeds by burning would have taken place in the spring (Law 1998), with people returning to the area later in the year to harvest the plants when they reached their maximum height.

The archaeological evidence also suggests that the organization of activity within the landscape was bound up in cultural practices as well as economic concerns. To begin with, the decisions to occupy places in the landscape were not solely dictated by the availability of environmental resources. As has been discussed, many sites around the lake were revisited on multiple occasions (e.g. Conneller \& Schadla-Hall 2003). Where these have been dated, we see recursive patterns of activity, often spanning centuries, during which time the character of the local wetland and terrestrial environments changed significantly (Taylor 2011, 77-8; 2012, 456). In these cases, it is difficult to see how there can be a consistent relationship between occupation and the availability of resources, and instead these places appear to have been regarded as appropriate locations to visit. Furthermore, from the variability in the forms and scales of activity that occurred at these locations (e.g. Conneller \& SchadlaHall 2003), the appropriateness of such places was not defined in terms of specific practices. Rather, these were appropriate places where (and perhaps when) broad suites of tasks could be undertaken.

Such patterns are well attested in the ethnographic record of traditional hunting and gathering societies in the northern regions of Eurasia and America. Jordan (2003a), for example, describes how the landscapes of the Khanty include sacred areas where hunting or gathering are prohibited, and places, often defined by environmental or topographic features, where economic tasks, feasting, or acts of deposition are carried out. Similarly, Nelson (1983) mentions how specific locations in the landscape of the Koyukon are considered lucky and are re-visited during hunting or foraging expeditions, while Hill (2012) describes how locations are actively avoided or afforded special treatment by indigenous hunting societies in areas of Alaska, Canada and Greenland. These ways of moving through and acting within the landscape relate to people's interactions with what would be described in a western ontology as 'supernatural' forces, including animals and plants that are considered to be sentient and self-aware and guardian spirits that protect them, ancestral spirits, and a suite of other 'non-human persons' (e.g. Jordan 2003a; Nelson 1983).

The archaeological evidence also suggests that people were selectively utilizing certain materials for particular tasks. Red deer antler was used exclusively for the manufacture of projectile points (Conneller 2011, 62), while bone scraping tools and bodkins were made from the metapodial elements of aurochs and elk, respectively (see Clark 1954, 16062). And while we cannot see it archaeologically, food plants are likely to have been selected for their taste, flavour and appropriateness as something to be consumed (e.g. Milner 2005), while plant materials may have been used selectively for certain tasks, a pattern that has been observed by Price (2009) in the Danish Mesolithic. Comparable practices are also documented ethnographically and again relate to an ontology where aspects of the environment are considered to be animate. The Mescalero and Chiricahua Apache, for example, considered some plants to be gendered and would use them for specific tasks (Castetter \& Opler 1936,17), while Nelson $(1983,52)$ describes how the Koyukon believe a particular plant to be malevolent and will avoid using it. Though we should be cautious in drawing direct ethnographic parallels, the similarity in practices suggests that comparable beliefs structured the way Mesolithic groups interacted with their environment.

Finally, there is evidence for deliberate forms of deposition and disposal of materials deriving from or relating to economic activities, that again show marked similarities with practices documented in the ethnographic record that relate to appropriate ways of engaging with the environment (e.g. Hill 2012; Jordan 2003a; Nelson 1983; and see also Conneller 2004). The best known is Star Carr, where osseous material culture, animal remains and worked flint were decommissioned and/or curated and then deposited into the lake (Taylor et al. 2017). However, comparable acts of deposition have also been recorded at other sites. Excavations at No Name Hill recovered a tranchet axe head and a complete barbed point from the lake-edge deposits (Taylor 2011, 76-7) and fragments of three more points have been identified from the faunal assemblage from the site (Ben Elliott pers. comm., 2015). The combination of complete and broken points and the absence of associated shafts or handles suggest comparable practices of decommissioning and curation to those recorded at Star Carr. At Flixton SHF, a small assemblage of aurochs bone 


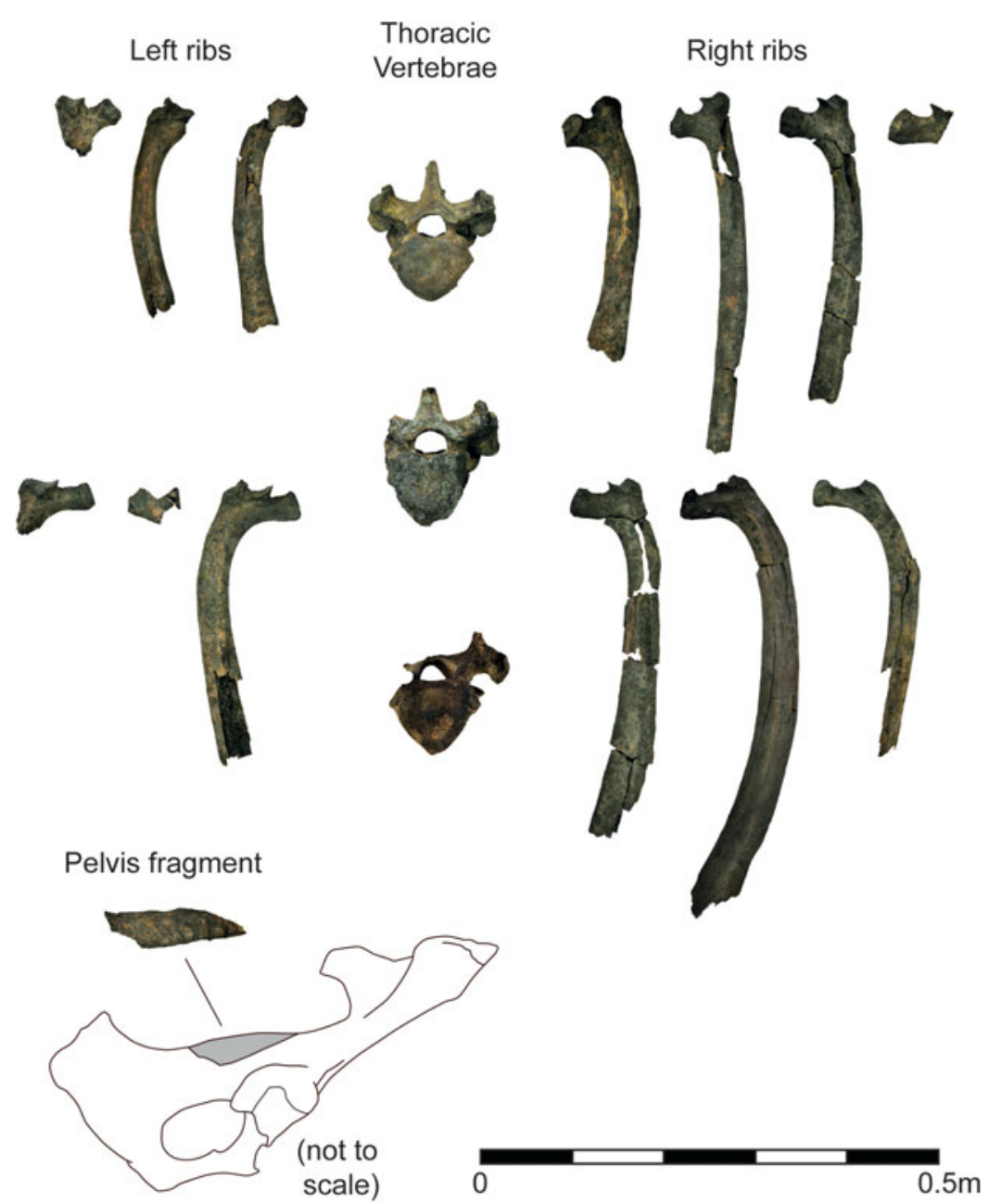

Figure 4. (Colour online) Aurochs bones from Flixton SHF (Overton \& Taylor in press).

that had either been placed in a bag or bound together was recorded from deposits that formed in a small pond adjacent to the lake (Overton \& Taylor in press) (Fig. 4), and a peck-marked stone was found deliberately broken and placed over a pit containing the waste from hazelnut roasting (Gray Jones \& Taylor 2015) (Fig. 5). Finally, Conneller (2000; 2005) identified caches of flint nodules at several sites around the lake. Though we lack the exact motivation behind these depositional acts, their similarity to practices described in the ethnographic literature strongly suggests that they relate to cultural rules regarding appropriate ways of engaging with the environment. If we accept this, then we should also consider that aspects of subsistence practice, such as the locations where animals were hunted, the species of plants that were collected and the locations that people occupied may also have been dictated by cultural as well as ecological factors.
Taken together, the evidence from sites around the lake and our understanding of the environment describes recursive patterns of activity organized around the availability of resources, but also structured through established ways of inhabiting the landscape. These were articulated through acts of deposition and the repeated occupation of appropriate places, and by implication specific ways of moving through the landscape. The following section will consider how the identification of these recursive patterns of activity can be used to apprehend something of the way in which Mesolithic groups inhabited the landscape around Lake Flixton.

\section{Discussion: inhabiting Lake Flixton}

The years following the arrival of Mesolithic groups saw a burst of activity around the lake. Most of the evidence for this earliest period of occupation comes 


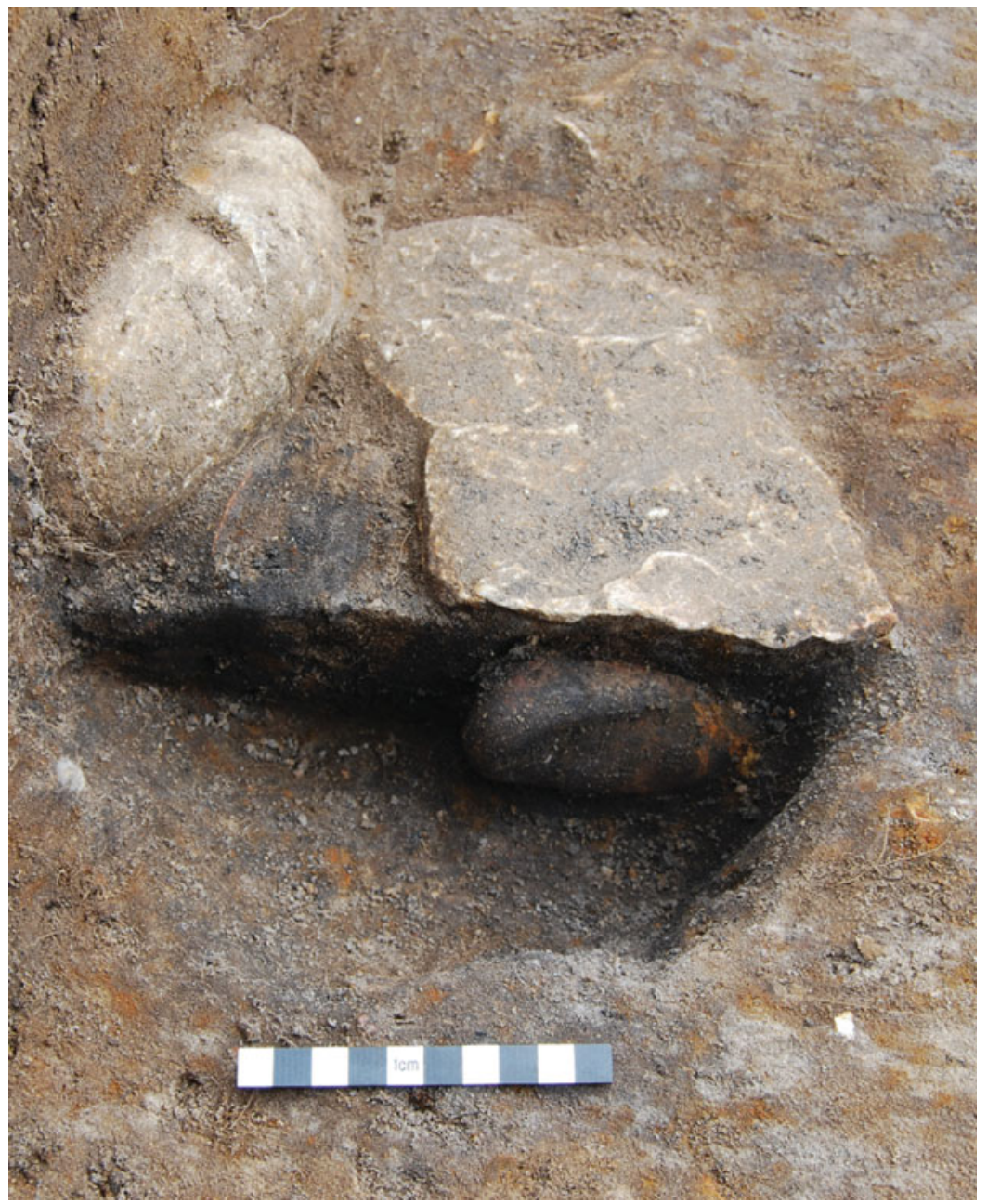

Figure 5. (Colour online) Pit containing hazelnut roasting debris from Flixton SHF. The large cobble (left) has been utilized and deliberately broken.

from Star Carr, but relates to a suite of different tasks that were being undertaken at a range of locations within the landscape. Some tasks were carried out within the vicinity of the site. Here people used flint flakes and blades to collect species of reed growing at the water's edge, used axes to cut long, straight willow stems from stands of natural or managed coppice, felled larger trees (both willow and aspen) growing in areas of denser woodland, and gathered wood for fuel. If they were consuming similar food plants to other groups in Northern Europe, then people also waded into the reedswamp along the shore and used digging sticks and baskets to collect the rhyzomes of bulrush, and used watercraft to harvest the seed pods of water-lilies growing in deeper water nearby.

Other tasks took people to different places around the lake, where they hunted, set traps and snares and collected plants. Groups of people armed with projectiles visited thickets of willow and aspen to track and kill animals such as red deer and elk, or locations at the water's edge to ambush other large mammals as they came to drink. In other cases people hunted or trapped beaver, possibly waiting in ambush next to lodges in the lake or at areas of the shore rich in aspen where the animals came to feed, caught pike and perch using projectiles or spears at the water's edge or from watercraft, and set and checked deadfall traps and snares in areas of the terrestrial landscape where pine marten and other mammals were active.

Journeys to these, and other locations involved encounters with different environments as people followed paths through areas of woodland to reach locations inland from the lake, waded through reedswamp to access discrete stands of particular wetland plants and skirted around dense, impenetrable thickets of willow and aspen. Other journeys were 
taken in boats, probably made from birch bark or animal hide on wooden frames. Here people launched amongst the beds of reeds and sedges growing at the shore before paddling through communities of waterlilies into open water as they headed to either of the islands, or to locations at other points along the lake shore.

These journeys, and the tasks that were associated with them, probably took people to other sites around the lake where evidence for very early episodes of Mesolithic activity has also been recorded. At No Name Hill, people were using flint flakes and blades, as well as composite tools incorporating microliths, within the reedswamp on the north shore of the island, and were bringing parts of the carcasses of animals (including red deer, elk and wild boar) onto the site (Taylor 2011, 77; 2012, 410). People were also using flint flakes and blades as well as formal tools at the water's edge and on the drier ground above the shore (Conneller 2000). Flint blades in the earliest deposits at Flixton Island (Site 1) and Flixton SHF also attest to broadly contemporary phases of activity at these locations, again involving tasks carried out within or at the edges of the reedswamp (Taylor 2012, 457-8), and again some of the activity on the adjacent dryland is probably contemporary.

We currently lack the chronological resolution necessary to determine how the episodes of activity we see archaeologically formed parts of broader patterns of settlement and mobility, and how these may have varied either seasonally or inter-annually. As discussed, if the seasonality data from Clark's assemblage at Star Carr are representative of activity at the site more generally, then the main focus of occupation may have been in the earlier part of the year, with less intensive activity in the later summer and autumn. However, whether this reflects an annual pattern of seasonal of mobility with groups visiting the area at different times and for different reasons, or inter-annual variations in the timing and character of occupation, is difficult to determine. What we can say is that, during particular visits to the landscape, different tasks created recursive patterns of movement and action of differing temporal and spatial scales around the lake. Some tasks were associated with specific moments, such as the initial arrival of a group at a site when people worked together to collect long stems used to make the frames for structures, and harvested reeds or bark to be worked into material for the walls, roof and floor. Others operated on routine cycles, such as the daily collection of firewood or the checking of traps and snares, or regular hunting, fishing or foraging expeditions. To some extent these patterns of movement and action were structured around the spatial and temporal availability of particular plants and animal: particular not only in the case of the specific species, but also age (in the case of animals) and growth patterns (in the case of plants). However, as has been discussed, cultural factors may also have dictated the choice of plant and animal species that were targeted, influencing the ways in which people moved through and acted within the landscape.

As subsequent generations occupied this landscape, they continued to return to the same locations. While the initial visit to these sites may have been motivated by economic concerns, such as the availability of particular resources, something about them, or their history, marked them out as appropriate places to return to (cf. Mithen 2000, 606). As has been discussed, some of these locations were also marked through acts of deposition and disposal relating to subsistence activities, notably hunting, but also plant use and flint working. As Jordan (2003b) has argued, such recursive structures of activity, where patterns of movement, occupation, economic practice and related acts of disposal and deposition are bound up in the cosmological significance of particular places, animals and plants, enculturate the landscape. As he states, the act of inhabiting these landscapes articulates particular ways of understanding the world, which are both structured by and recreated through participation in the routine habitual practices of daily life.

Around Lake Flixton these ways of inhabiting the landscape were both historical, referencing earlier episodes of occupation, and dynamic, changing throughout much of the early Mesolithic. To begin with, patterns of movement and activity associated with economic practices would have changed throughout the period as both the wetland and terrestrial environments developed. The expansion of swamp environments into the shallower parts of the basin and the embayments at Seamer Carr and Lingholme, the development of fen and carr at the shore, and the appearance and subsequent expansion of hazel across the terrestrial landscape would have altered the habitats of different animals and the presence and abundance of different plant species. The scale and intensity of activity around the lake also suggests that decisions as to the appropriateness of particular locations (and by implications ways of moving through the landscape) were dynamic. As discussed earlier, if we take the evidence for localized burning events at Flixton School Field, No Name Hill (Cummins 2003) and Star Carr (Dark 1998; Dark et al. 2006) as proxies for human activity, then there is considerable variation in the intensity of occupation at these (and potentially other) locations through time. Crucially, sites were not abandoned permanently, but 
were reoccupied after decades or centuries, suggesting relatively short-term responses to specific events, such as the death of an individual or the associations of particular places with bad luck (e.g. Lavrillier 2016).

To the Mesolithic groups that inhabited the area, this was a landscape rich in history. The routine practices of daily life drew upon existing understandings of appropriate forms of behaviour when making decisions as to the places people visited, the plants and animals they collected or hunted, the ways certain materials were used, and methods of disposal and deposition. Particular places were known as areas suitable for the hunting or trapping of certain animals, or the collection of particular plants, or as locations that were appropriate for occupation or other forms of activity. These places were marked by the residues of previous visits, such as the remains of hearths or structures, ground disturbance and changes in vegetation, but also by the memories of past events and knowledge of their wider cosmological significance. Some of these places were sought out and revisited, the tasks undertaken there articulating existing understandings of that location and its wider significance while adding to the physical and mnemonic residues associated with it. Others were actively avoided, the physical remains of earlier occupation acting to remind people of their inappropriateness, and the possibilities of danger.

This understanding of the landscape was learnt, articulated and recreated (at least in part) through the economic practices that people undertook. These took people to different parts of their landscape, at different times, and with different members of the community, and involved interactions with different plants and animals. These interactions were physical, involving bodily strength and kinaesthetic knowledge deployed in the use of weapons or tools and the handling and working of plant materials and the bodies of animals. And they were also skilled, requiring a suite of technical and cultural knowledge that related to the geography of the landscape, the ecology, behaviour and properties of plants and animals, and the appropriate ways of conducting oneself in relation to the world.

These sets of skill and knowledge would be specific to individuals and situated at particular points in their lives. Practices would be learnt, either through direct instruction, observation of others, or active participation, but would develop through time as existing skills were honed and understanding was enhanced through experience. What is more, if we assume that the way people participated in tasks related to aspects of their identity, such as gender and age, then these abilities would vary between individ- uals, while also changing throughout the course of their lives. These tasks were also inherently social, involving interactions with different people, from members of the immediate family and peer group to wider kin-networks and the community as a whole. Within these different contexts, interactions would have been bound up in broader social relations, such as family or other social hierarchies, peer relationships and gender and age divisions, which would be articulated through participation in a particular task.

Far from determining the nature of subsistence, the environment was intricately bound into it, and through this into the lives of the people inhabiting this landscape. Subsistence tasks, which formed a medium through which people engaged with their environment, were also a forum for social interaction and the means by which different social relationships were articulated. It was this interplay between the physical nature of the environment, the cultural attitudes towards it and the array of technical and social practices through which people engaged with it and each other, that ultimately shaped the lives and livelihoods of Mesolithic people.

\section{Conclusion}

This way of thinking about the Lake Flixton landscape (and Mesolithic landscapes more generally) provides a very different account from the more traditional, economically focused narratives that continue to influence our understanding of the period, and expands upon more recent studies that have explored the ways in which Mesolithic people understood the world they inhabited. To begin with, the relationship between economic activity and the environment is demonstrably more complex than previous accounts have suggested, involving a dynamic interplay between a suite of different subsistence tasks and highly varied plant and animal communities. Particular tasks took people to specific places at certain times, creating recursive patterns of activity that varied in character and scale and that changed as the local environments developed. And while activity was organized around the spatial and temporal patterning of the environment, it was also structured by cultural attitudes towards particular plants, animals and places in the landscape.

The result is a richer account of people's lives, one in which human action was based upon knowledge, experience and an understanding of the world. Achieving this requires us to reconfigure the way we think about subsistence and the principles through which it was organized. We must move away from broad categories of economic activity (such as 
hunting, gathering or fishing) to the specifics of subsistence practice in order to pick apart the complex relationships between people and their environment. Lithic scatters, faunal assemblages and palaeobotanical remains all provide evidence for the different forms of activity that people undertook, the attendant knowledge, skill and technologies they involved, and the interactions they created with particular plant and animal communities. From this we can explore the different temporal and spatial scales that such activities operated on, the recursive patterns of activity they created within the landscape, and how these would have been structured (at least in part) by the variability in the local environment. Where palaeoecological data is present, this latter point can be explored further by mapping different forms of activity onto the spatial and temporal patterning of the local environment.

We must also recognize that subsistence practices were structured by cultural factors, and that this is reflected in the formation of the archaeological record. Formal practices of deposition and disposal, often associated with economic tasks, were taking place during the European Mesolithic and are reflected in the character of faunal and artefact assemblages (see Taylor et al. 2017). By reassessing assemblages that have previously been interpreted in purely economic terms, we may begin to identify patterns in the treatment of particular plants, animals and other materials that could lead to a better understanding of the underlying principles through which subsistence practice was organized. Equally, the fact that Mesolithic people returned to the same locations, and that this may relate to cultural as well as economic factors, has already been recognized (e.g. Barton et al. 1995; Mithen 2000). Again, identifying comparable patterns of occupation at other locations, and establishing more detailed chronologies for them, will help us to see how these 'persistent places' formed part of a structure to the way Mesolithic groups inhabited their landscape.

Finally, we need to accept that subsistence practices were underpinned by decisions made by knowledgeable social actors employing skill, technical aptitude and an understanding of the world. Only in this way can we appreciate the true complexity of the way people inhabited their landscapes, and of life and livelihood in the Mesolithic.

\section{Acknowledgements}

This paper arose from my doctoral research, which was funded by the Arts and Humanities Research Council (AHRC Doctoral Award 2007/135399). Thanks to Paul Lane for allowing me access to the unpublished archives of the
Vale of Pickering Research Trust, and to Nick Overton, Chantal Conneller and Nicky Milner for their comments on an earlier draft of this paper. Thanks are also due to Amy Gray Jones for the thought-provoking and insightful discussions that led to this paper being written, and to the two anonymous referees and John Robb, whose comments improved the paper significantly.

Barry Taylor Department of History \& Archaeology University of Chester Chester CH1 4BJ

UK

Email:b.taylor@chester.ac.uk

\section{References}

Amkreutz, L., 2013. Persistent Traditions. A long term perspective on communities in the process of Neolithisation in the Lower Rhine Area. Leiden: Sidestone Press.

Bamforth, M., M. Taylor, B. Taylor, H. Robson, A. Radini \& N. Milner, in press. Wooden structures, in Star Carr. A persistent place in a changing world, by N. Milner, C. Conneller \& B. Taylor. York: White Rose University Press.

Barton, R.N.E., P.J. Berridge, M.J.C. Walker \& R.E. Bevins, 1995. Persistent places in the Mesolithic landscape: an example from the Black Mountain uplands of South Wales. Proceedings of the Prehistoric Society 61, 81-116.

Boas, F., 1905. The Kwakiutl of Vancouver Island. Leiden: E.J. Brill.

Bonsall, C., 1981. The coastal factor in the Mesolithic settlement of north-west England, in Mesolithikum in Europa, ed. B. Gramsch. Berlin: Deutscher Verlag, 451-72.

Bonsall, C., 1996. The 'Obanian' problem: coastal adaptation in the Mesolithic of western Scotland, in The Early Prehistory of Scotland eds. A. Pollard \& A. Morrison. Edinburgh: Edinburgh University Press, 183-97.

Carter, R.J., 1997. Age estimation of the roe deer (Capreolus capreolus) mandibles from the Mesolithic site of Star Carr, Yorkshire, based on radiographs of mandibular tooth development. Journal of Zoology 24, 495-502.

Carter, R.J., 1998. Reassessment of seasonality at the early Mesolithic site of Star Carr, Yorkshire, based on radiographs of mandibular tooth development in red deer (Cerous elaphus). Journal of Archaeological Science 25, 851-6.

Castetter, E.F. \& M.E. Opler, 1936. Ethnobiological Studies in the American Southwest, III: The ethnobiology of the Chiricahua and Mescalero Apache. (University of New Mexico Bulletin 297, Biological Series 4(5).) Albuquerque (NM): University of New Mexico Press.

Chatterton, R., 2003. Star Carr reanalysed, in Peopling the Mesolithic in a Northern Environment, eds. J. Moore \& L. Bevan. (BAR International series S1157.) Oxford: Archaeopress, 69-80. 
Clark, J.G.D., 1954. Excavations at Star Carr. Cambridge: Cambridge University Press.

Clark, J.G.D., 1972. Star Carr: A case study in bioarchaeology. Reading: Addison-Wesley Modular Publications.

Cobb, H.L., 2007. Media for movement and making the world: exploring materiality and identity in the Mesolithic of the northern Irish Sea Basin. Internet Archaeology 22. https:/ / doi.org/10.11141/ia.22.6

Conneller, C., 2000. Space, Time and Technology: The Early Mesolithic of the Vale of Pickering, North Yorkshire. Unpublished PhD thesis, University of Cambridge.

Conneller, C., 2004. Becoming deer: corporeal transformations at Star Carr. Archaeological Dialogues 11, 37-56.

Conneller, C., 2005. Moving beyond sites: Mesolithic technology in the landscape, in Mesolithic Studies at the Beginning of the 21st Century, by N. Milner \& P. Woodman. Oxford: Oxbow, 42-55.

Conneller, C., 2011. An Archaeology of Materials: Substantial transformations in early prehistoric Europe. Oxford: Routledge.

Conneller, C., A. Bayliss, N. Milner \& B. Taylor, 2016. The resettlement of the British landscape: towards a chronology of Early Mesolithic lithic assemblage types. Internet Archaeology 42. https://doi.org/10. $11141 /$ ia. 42.12

Conneller, C., N. Milner, B. Taylor \& M. Taylor, 2012. Substantial settlement in the European early Mesolithic: new research at Star Carr. Antiquity 86, 1004-20.

Conneller, C. \& R.T. Schadla-Hall, 2003. Beyond Star Carr: the Vale of Pickering in the tenth millennium BP. Proceedings of the Prehistoric Society 69, 85-105.

Cummins, G., 2003. Impacts of Hunter-Gatherers on the Vegetation History of the Eastern Vale of Pickering, Yorkshire. Unpublished PhD thesis, Durham University.

Dark, P., 1998. Palaeoecological investigations, in Star Carr in Context: New archaeological and palaeoecological investigations at the early Mesolithic site of Star Carr, North Yorkshire, by P. Mellars \& P. Dark. Cambridge: McDonald Institute for Archaeological Research, 111-208.

Dark, P., T.F.G., Higham, R. Jacobi \& T. Lord, 2006. New radiocarbon accelerator dates on artefacts from the early Mesolithic site of Star Carr, North Yorkshire. Archaeometry 48(1), 185-200.

Donahue, R.E. \& W.A. Lovis, 2006. Regional settlement systems in Mesolithic northern England: Scalar issues in mobility and territoriality. Journal of Anthropological Archaeology 25, 248-58.

Edmonds, M.R., 1997. Taskscape, technology and tradition. Analecta Praehistorica Leidensia 29, 99-110.

Ellis, C., J. Allen, J. Gardiner, P. Harding, C. Ingrem, A. Powell \& R. Scaife, 2003. An early Mesolithic seasonal hunting site in the Kennet Valley, southern England. Proceedings of the Prehistoric Society 69, 107-36.

Gray Jones, A. \& B. Taylor, 2015. Excavations at Flixton School House Farm, North Yorkshire UK. 2008-9. Unpublished archive report, University of Chester.
Hall, S.J.G., 2008. A comparative analysis of the habitat of the extinct aurochs and other prehistoric mammals in Britain. Ecography 31, 187-90.

Healy, F., M. Heaton \& S.J. Lobb, 1992. Excavation of a Mesolithic site at Thatcham, Berkshire. Proceedings of the Prehistoric Society 58, 41-76.

Hill, E., 2012. The nonempirical past: enculturated landscapes and other-than-human persons in southwest Alaska. Arctic Anthropology 49(2), 41-57.

Jacobi, R., 1978. Northern England in the eighth millennium bc: an essay, in The Early Post Glacial Settlement of Northern Europe. An ecological perspective, ed. P. Mellars. London: Duckworth, 295-332.

Jarvenpa, R. \& H.J. Brumbach, 2006. Chipewyan society and gender relations, in Circumpolar Lives and Livelihood. A comparative ethnoarchaeology of gender and subsistence, eds. R. Jarvenpa \& H.J. Brumbach. Lincoln/London: University of Nebraska Press, 24-53.

Jochim, M.A., 1976. Hunter-Gatherer Subsistence and Settlement. A predictive model. New York (NY): Academic Press.

Jochim, M.A., 1991. Archaeology as long term ethnography. American Anthropologist 93, 309-19.

Jochim, M.A., 1998. A Hunter-gatherer Landscape. Southwest Germany in the late Palaeolithic and Mesolithic. New York/London: Plenum Press.

Jolles, C.Z., 2006. Inupiaq maritime hunters: summer subsistence work in Diomede, in Circumpolar Lives and Livelihood. A comparative ethnoarchaeology of gender and subsistence, eds. R. Jarvenpa \& H.J. Brumbach. Lincoln/London: University of Nebraska Press, 263-86.

Jordan, P., 2003a. Material Culture and Sacred Landscape. Walnut Creek (CA): Altamira Press.

Jordan, P., 2003b. Investigating post-glacial hunter-gatherer landscape enculturation: ethnographic analogy and interpretive methodologies, in Mesolithic on the Move. Papers presented at the sixth international conference on the Mesolithic in Europe, Stockholm 2000, eds. L. Larsen, H. Kingren, K. Knutsson, D. Loeffler \& A. Akerlund. Oxford: Oxbow, 128-38.

Lane, P. \& R.T. Schadla-Hall, forthcoming. Hunter-Gatherers in the Landscape: Investigations of the early Mesolithic in the Vale of Pickering, North Yorkshire, 1976-2000. Cambridge: McDonald Institute for Archaeological Research.

Lavrillier, A., 2016. The creation and persistence of cultural landscapes among the Siberian Evenkis: two conceptions of 'sacred' space, in Landscape and Culture in Northern Eurasia, ed. P. Jordan. Walnut Creek (CA): Left Coast Press, 215-31.

Law, C., 1998. The uses and fire-ecology of reedswamp vegetation, in Star Carr in Context: New archaeological and palaeoecological investigations at the early Mesolithic site of Star Carr, North Yorkshire, by P. Mellars \& P. Dark. Cambridge: McDonald Institute for Archaeological Research, 197-206. 
Leduc, C., 2014. New Mesolithic hunting evidence from bone injuries at Danish Maglemosian sites: Lunby Mose and Mullerup (Sjælland). International Journal of Osteoarchaeology 24(4), 476-91.

Legge, A. \& P. Rowley-Conwy, 1988. Star Carr Revisited: A reanalysis of the large mammals. London: Centre for ExtraMural Studies.

McFadyen, L., 2006. Landscape, in Mesolithic Britain and Ireland: New approaches, eds. C. Conneller \& G. Warren Stroud: Tempus, 121-38.

McGuire, K. \& W. Hildebrandt, 1994. The possibilities of women and men: gender and the California Milling Stone Horizon. Journal of California and Great Basin Anthropology 16(1), 41-59.

Mellars, P., 1976. Settlement patterns and industrial variability in the British Mesolithic, in G. Sieveking, I.H. Longworth \& K.E. Wilson (eds), Problems in Economic and Social Archaeology. London: Duckworth, 357-99.

Mellars, P., 1998. Postscript: major issues in the interpretation of Star Carr, in Star Carr in Context: New archaeological and palaeoecological investigations at the early Mesolithic site of Star Carr, North Yorkshire, by P. Mellars \& P. Dark. Cambridge: McDonald Institute for Archaeological Research, 215-42.

Mellars, P. \& C. Conneller, 1998. Lithic assemblages, in Star Carr in Context: New archaeological and palaeoecological investigations at the early Mesolithic site of Star Carr, North Yorkshire, by P. Mellars \& P. Dark. Cambridge: McDonald Institute for Archaeological Research, 8398.

Mellars, P. \& S.C. Reinhardt, 1978. Patterns of Mesolithic land-use in southern England: a geological perspective, in The Early Post Glacial Settlement of Northern Europe. An ecological perspective, ed. P. Mellars. London: Duckworth, 243-94.

Milner, N., 2005. Seasonal consumption practices in the Mesolithic: Economic, environmental, social or ritual?, in Mesolithic Studies at the Beginning of the 21st Century, eds. N. Milner \& P.C. Woodman. Oxford: Oxbow Books, 56-67.

Milner, N., C. Conneller \& B. Taylor, in press. Star Carr. A persistent place in a changing world. York: White Rose University Press.

Mithen, S., 1990. Thoughtful Foragers. A study of prehistoric decision making. Cambridge: Cambridge University Press.

Mithen, S. (ed.), 2000. Hunter-gatherer Landscape Archaeology: The southern Hebrides Mesolithic project. Cambridge: Macdonald Institute for Archaeological Research.

Myres, A., 2015. A flint for all seasons? The organisation of settlement and technology in the Earlier Mesolithic of northern England, in No Stone Unturned: Papers in honour of Roger Jacobi, eds. N. Ashton \& C. Harris. London: Lithic Studies Society, 167-90.

Nelson, R., 1983. Make Prayers to the Raven. A Koyukon view of the northwest forest. Chicago (IL): Chicago University Press.
Nelson, R., 1986. Hunters of the Northern Forest. Designs for survival among the Alaskan Kutchin (2nd edition). Chicago (IL): University of Chicago Press.

Noe-Nygaard, N., 1974. Mesolithic hunting in Denmark illustrated by bone injuries caused by human weapons. Journal of Archaeological Science 1, 217-48.

Noe-Nygaard, N., 1975. Two shoulder blades with healed lesions from Star Carr. Proceedings of the Prehistoric Society 41, 10-16.

Out, W., 2009. Sowing the Seed? Human impact and plant subsistence in Dutch wetlands during the Late Mesolithic and Early and Middle Neolithic (5500-3400 cal BC). Leiden: Leiden University Press.

Overton, N. \& B. Taylor, in press. Humans in the environment: plants, animals and landscapes. Journal of World Prehistory.

Perry, D. 1999. Vegetative tissues from Mesolithic sites in the northern Netherlands. Current Anthropology 40(2), 231-7.

Price, S., 2009. Wood and wild animals: towards an understanding of a Mesolithic world, in Mesolithic Horizons. Papers presented at the seventh international conference on the Mesolithic in Europe, Belfast 2005, eds. S. McCartan, R. Schulting, G. Warren \& P. Woodman. Oxford: Oxbow, 683-9.

Price, T.D. 1978. Mesolithic settlement systems in the Netherlands, in The Early Post Glacial Settlement of Northern Europe. An ecological perspective, ed. P. Mellars. London: Duckworth, 81-114.

Ripple, W.J. \& R.L. Beschta, 2004. Wolves and the ecology of fear: can predation risk structure ecosystems? BioScience 54(8) 755-66.

Robson, H.K., A. Little, A.K.G. Jones, et al., 2016. Scales of analysis: evidence of fish and fish processing at Star Carr. Journal of Archaeological Science: Reports. https: / / doi.org/10.1016/j.jasrep.2016.02.009

Rowley-Conwy, P., 1995. Mesolithic settlement patterns: new zoological evidence from the Vale of Pickering, Yorkshire. University of Durham and University of Newcastle upon Tyne Archaeological Reports 1994, $1-6$.

Simmons, I.G., 1975. The ecological setting of Mesolithic man in the highland zone, in The effect of Man on the Landscape: The highland zone, eds. J.G. Evans, S. Limbrey \& H. Cleere. (CBA research report 11.) York: Council for British Archaeology, 57-63.

Spikins, P.A., 1999. Mesolithic Northern England. Environment, population and settlement. (BAR British series 283.) Oxford: British Archaeological Reports.

Taylor, B., 2011. Early Mesolithic activity in the wetlands of the Lake Flixton Basin. Journal of Wetland Archaeology 11(1), 63-84.

Taylor, B., 2012. The Occupation of Wetland Landscapes during the British Mesolithic: Case Studies from the Vale of Pickering. Unpublished PhD thesis, University of Manchester.

Taylor, B., B. Elliot, C. Conneller, N. Milner, A. Bayliss, B. Knight \& M. Bamforth, 2017. Resolving the issue 
of artefact deposition at Star Carr. Proceedings of the Prehistoric Society 83, 23-42.

Taylor, B. \& A. Gray Jones, 2009. Definitely a pit, possibly a house? Recent excavations at Flixton School House Farm in the Vale of Pickering. Mesolithic Miscellany 20(2), 21-6.

Taylor, M., 1998. Identification of the wood and evidence for human working, in Star Carr in Context: New archaeological and palaeoecological investigations at the early Mesolithic site of Star Carr, North Yorkshire, by P. Mellars \& P. Dark. Cambridge: McDonald Institute for Archaeological Research, 52-63.

Uchiyama, J., 2016. From Awashimadai to Star Carr: a Japanese Jomon perspective on the subsistence strategies and settlement patterns of Early Mesolithic hunter-gatherers in the Vale of Pickering, UK. Quaternary International 419, 17-26.

Van Gijn, A., Y. Lammers-Keijsers \& R. Houkes, 2001. Vuursteen, in Hardinxveld-Giessendam de Bruin. Een kampplats uit het Laat-Mesolithicum en het begin van de Swifterbant-cultuur (5500-4500 v. Chr), eds. L.P. Louwe-Koojimans, E.A.G. Ball, C.C. Bakels, et al. (Rapportage Archeologische Monumentenzorg 88.) Amersfoort: Rijksdienst voor het Oudheidkundig Bodemonderzoek, 153-92.

Willoughby, N.C. 1963. Division of labor among the Indians of California. Reports of the University of California Archaeological Survey 60, 7-79.

\section{Author biography}

Barry Taylor is Senior Lecturer in Archaeology at the Department of History and Archaeology, University of Chester. He has worked extensively in the eastern Vale of Pickering, co-directing the excavations at the Mesolithic sites of Star Carr and Flixton School House Farm (the latter with Amy Gray Jones). He has also undertaken extensive palaeoenvironmental surveys of the area, reconstructing the changing character of the wetland environments and establishing the relationship to patterns of human action and the local plant and animal communities. 